\title{
Türkiye'de Organik Süte Yönelik Potansiyel Talebin Tahminlenmesi
}

\section{Nilgün Doğan (D) Semiha Kızıloğlu Abdulbaki Bilgiç D \\ Atatürk Üniversitesi Ziraat Fakültesi Tarım Ekonomisi Bölümü, Erzurum \\ $\varangle$ : nilgun_stu@hotmail.com}

\section{ÖZET}

Araştırma, Türkiye'de henüz iç piyasada yeni olan ve yoğun girdi kullanımı yerine organik üretim teknikleri kullanılarak üretilen ve bu özellikleri Tarım ve Orman Bakanlığının belirlediği güvenilir bir kurum tarafından sertifikalandırılan organik süt için iç piyasada talebin varlığını ve tüketicilerin ödeme isteğinin ne olduğunu ortaya koymayı hedeflemektedir. Bu amaca ulaşmak için Koşullu Değerleme yöntemi kullanılmıştır. Araştırmada kullanılan veriler, Türkiye'de yedi bölgede belirlenen on dört ilde 2016 yılında Haziran ayında yüz yüze yapılan görüşmelerden elde edilmiştir. Elde edilen sonuçlara göre; sütün organik olma özelliği konusunda, fazladan ödeme yapma olasılıği; satın alınan miktar ve gelir ile doğru orantılı olarak artmaktadır ve yüksek gelir grubunda bulunan hanelerin \%53 daha fazla ödeme yapma olasılığında oldukları belirlenmiştir. Buna ilaveten, ödeme yapma olasılığının; içinde kalıntı olmadığı garanti edilmiş olan sütün fiyatı yükseldikçe, azaldığı saptanmıştır. Hanelerin litre başına ortalama kabul ettikleri ödeme istekliliği fiyatı organik sütte 5.17 TL olarak bulunmuştur. Modelde ele alınan bölgeler değişkenine bakıldığında, Marmara bölgesinde yaşayan haneler modelde referans alınan bölgeye göre 1 litrelik organik süt için mevcut piyasa fiyatı üzerinden 68 kuruş daha az ödeme istekliliği olasılığında oldukları elde edilen bulgularla desteklenmektedir. Bu sonuçlara ilaveten organik süt için fiyat pirimi ödemeyi kabul eden tüketici grubundan hedef pazarın özellikleri ile ilgili bilgi elde edilebileceği söylenebilir.
\end{abstract}

\section{Estimating the Potential Demand for Organic Milk in Turkey}

\section{ABSTRACT}

Organic milk is new in the domestic market and is produced using organic production techniques certified by Ministry of Agriculture Forestry. This research aims to reveal the existence of organic milk demand in the domestic market and willingness to pay. To reach this aim contingent valuation method was used. The data used in the study was obtained from face to face interviews conducted in identified fourteen provinces ofnTurkey in in June of 2016. According to research results; possibility of willingness to pay in respect of the organic nature of the milk; it is increasing in direct amount purchased and income. Willingness to pay is directly proportional with household income and $53 \%$ of high income households are willing to pay more. In addition it has been found that willingness to pay is decreasing as organic milk price increases. The average willingness to pay price per capia was found as 5.17 TL in organic milk. Regarding the region variables in the model, households that live in Marmara region to reference region would like to pay 0.68 TL less. In addition to these results, it can be said that the consumer group that accepts the price premium payment for organic milk may be able to obtain information about the characteristics of the target market.
Makale Tarihçesi

Geliş : 20.10.2018

Kabul : 27.12.2018

Anahtar Kelimeler

Organik Süt,

Talep,

Türkiye

\section{Araştırma Makalesi}

\section{Article History}

Received : 20.10.2018

Accepted : 27.12.2018

\section{Keywords \\ Organic Milk, \\ Demand, \\ Turkey}

\section{Research Article}


To cite: Doğan N, Kızıloğlu S, Bilgiç A 2018. Türkiye'de Organik Süte Yönelik Potansiyel Talebin Tahminlenmesi. KSÜ Tar Doğa Derg 21(Özel Sayı) : 35-43, DOI : 10.18016/ ksutarimdoga.vi.472829

\section{GİRIŞ}

Dünyadaki tarımsal üretim, doğal kaynaklara zarar vermeyecek şekilde ve tarımda sürdürülebilirliğin sağlanması yönünde değişmekte ve gelişmektedir. Çevreyi ve hayvan refahını düşünerek yapılan tarımsal üretimde ciddi şekilde gelişmeler ve olumlu sonuçlar alınmaktadır. Türkiye'de organik üretimle ilgili olarak; kimyasal girdilerin kullanılmaması, temiz topraklarda üretim yapılması, hastalıklarla mücadelede ilaç uygulanmaması, bitkisel üretim ile hayvansal üretimin bir sistem içerisinde yapılarak kaynakların ekonomik şekilde kullanılması doğrultusunda, üretim, politika ve yayım çalışmaları yapılmaktadır. Dünyada çevreyle dost üretimin başlamasıyla, 1980'li yıllarda Türkiye'de Avrupa'daki talebe yönelik organik üretim ilk defa başlamıştır (Demiryürek, 2011).

Araştırmaya konu olan organik süt; dünyada dikkat çekici bir şekilde konvansiyonel süt üretimi içerisinde payını almaktadır. Danimarka'da yılda 444000 ton, Almanya'da 370000 ton, Hollanda'da 90000 ton, Ingiltere'de 86000 ton, Avusturya'da 470000 ton, Fransa'da 144000 ton ve AB'de toplam 1788247 ton organik süt üretilmektedir. Organik süt üretiminin toplam süt üretimdeki payı Avusturya'da \%14,1, Danimarka'da \%9,4, İsveç'te \%3,0, Almanya'da \%1,3, AB-27'de \%1,5 olduğu bildirilmiştir (Anonim, 2014). Türkiye'de konvansiyonel süt içerisinde organik sütün oranı sadece \% 0,098'dir (Şengül ve Ürkek, 2013). Organik süt üretiminin bu kadar düşük olmasının nedenleri arasında; üreticinin organik üretime olan yetersiz inancı ve bilinci, organik üretimin kontrollü bir üretim şekli olması nedeniyle üreticinin isteksizliği, organik üretimdeki yüksek girdi maliyetleri, kimyasal girdiler kullanmadan verim alınamayacağı yargıları gibi nedenlerden dolayı bu sektörde yeterince yatırım yapılmamaktadır. Bu bağlamda, organik süt üretiminin artması bu alanda yapılacak yatırımlara bağlıdır (Doğan ve Kızıloğlu, 2015).

Ülkemizde organik ürün pazarı ile ilgili ciddi sıkıntılar mevcuttur. Organik ürün tüketim bilincinin yeterli ve organik ürün pazarının yaygın olmaması, ürün çeşidindeki azlık ve sertifika masrafları yani söz konusu maliyetlerin ürün fiyatına yansımasından dolayı potansiyel talebin olup olmamasinın araştırılması önem arz etmektedir. Tüketicilerin organik yöntemlerle üretilmiş ürünleri belli fiyattan satın almayı kabul etmeleri, bir başka deyişle potansiyel bir talebin olup olmamasiyla ilgilidir. $\mathrm{Bu}$ araştırmada hedeflenen soru, Türkiye'de iç piyasada kısitlı pazarlanan ve yoğun girdi yerine çevreyle dost üretim şekli benimsenerek özellikleri iyileştirilen ürün için iç piyasada potansiyel talebin varlığı ve tüketicinin söz konusu ürün için ödeme isteğinin ne olduğudur. Türkiye'de organik yöntem usul ve esaslarına göre üretilmiş ve Tarım ve Orman Bakanlığı'na (TOB) bağlı sertifika kurumları tarafından organik olarak sertifikalandırılmış ürün sayısı oldukça sınırlıdır. Araştırma kapsamına alınan ürün organik süttür. Türkiye'de sütle ilgili yapılan araştırmaların çoğunluğu tutum ve davranışları inceleyen araştırmalardır. Süt çeşitlerinin özellikle organik sütün tüketme miktarı ödeme istekliliği olasılığına etki eden sosyo-demografik ve ekonomik faktörleri araştıran çalışmalar kısıtlı ve ödeme istekliliği değerini ortaya koyan çalışmalar yok denecek kadar azdır.

$\mathrm{Bu}$ araştırmada, Türkiye'de hanelerin organik süt tüketme ödeme istekliliğine etki eden sosyodemografik ve ekonomik faktörler, yatay kesit verilerin sağladığı avantajla ayrıntılı bir şekilde elde edilmiştir. Organik yöntemlerle üretilen organik sütün ödeme istekliliğini ölçmede iki özellik kullanılmıştır. Bunlardan biri, ankete katılan hanelerin gelirlerinde bir artma olduğu ve diğeri sütün hiçbir katkı maddesi içermediği ve sertifikalı olması, dolayısıyla daha sağlıklı olduğudur. $\mathrm{Bu}$ şekilde özellikli malın tüketici açısından değeri, özellikli malların değerinin belirlenmesinde kullanılan bir yöntem olan koşullu değerleme yöntemiyle (KDY) belirlenmiştir. Araştırmada ulaşllan değer, daha sağlıklı olduğu garanti edilen sütün kullanım değeridir. Tüketicilerin organik yöntem usul ve esaslarına göre üretilen sütün daha sağlıklı ve ilaç kalıntısı içermemesi özelliği için ödemeyi kabul ettikleri fiyat hesaplanmıştır. Dolayısıyla, bu araştırmada tahminlenmesi hedeflenen ödeme isteği değeri, hanelerin organik yöntemlerle üretilen ürün için ödemeyi kabul ettikleri değerin alt sınırını vermektedir.

\section{MATERYAL ve METOT}

\section{Materyal}

Türkiye İstatistik Kurumu (TÜİK) ekonomik, nüfus ve kalkınma faktörlerini göz önünde bulundurarak Türkiye'yi Düzey 1 kapsamında sınıflandırmıştır. Bu sinıflandırmada, on iki İstatistiki Bölge Birimleri (12 İBBS) mevcut olup, araştırmada bu bölgelerden nüfus ve kalkınma durumlarına bakılarak en az bir il seçilmiştir. Toplamda on dört il araştırma kapsamına alınmıştır. İlgili illerde, yaşayan hane sayıları göz önünde bulundurularak anket sayıları oransal olarak dağıtılmıştır. anketler il ve/veya ilçe merkezlerinde yapılmıştır. Araştırma kapsamına alınan illerde her gelir grubundan hanelerin ankete katılımı sağlanmaya çalışılmıştır. Haliyle, diğer illerde yaşayan hanelerin de organik süte yönelik potansiyel 
talebi konusunda bir tahmin elde edilmiştir. Araştırmanın amacına uygun seçilen on dört il Konya, Adana, Erzurum, Malatya, Gaziantep, Trabzon, Samsun, Ankara, Antalya, İzmir, Bursa, İstanbul, Kayseri ve Diyarbakır'dır. Ana kitlenin hanehalkı olarak belirlenmesinin nedeni, araştırma kapsamına alınan organik süt alışverişinin genellikle o hanede yaşayan belli bir kişi tarafından yapılmasıdır. Koşullu değerleme anketinin içeriğini sosyo-demografik ve ekonomik faktörlerle ilgili sorular ve fiyatlandırma soruları oluşturmuştur. Alan çalışmasının ilk aşaması anket sorularının düzenlenmesidir. Sorular kapsamlı bir ön anket çalışmasıyla İstanbul, Ankara ve İzmir illerinde 100 denek üzerinde 2016 yılı Haziran ayında yapılmıştır. Anketi uygulayan anketörlerin gözlemleri dikkate alınarak anket sorularına son hali verilmiştir. Alan çalışmasının ikinci aşamasını anketör eğitimi oluşturmuştur. Bu amaca istinaden, İstanbul, Ankara ve Izmir'de sahada görev alacak anketörler, araştırmanın konusu, kapsamı ve sorular hakkında eğitilmişlerdir. Anketler tamamlandıktan sonra bir hafta içinde ankete katılan denekler arasından tesadüfi olarak belirlenen 500 tanesi, evlerine anketörün gelip gelmediği ve anketin uygulanıp uygulanmadığı konusunda kontrol etmek amacıyla telefonla aranmışlardır.

\section{Yöntem}

Araştırmada, örnek hacmi belirleme yöntemi olarak "Anakitle Oranlarına Dayalı Kümelendirilmemiş Tek Aşamalı Basit Tesadüfi Olasılık Örneklemesi” kullanılmıştır (Collins 1986). Bu yönteme göre, araştırmanın örnek büyüklüğü 1011 olarak bulunmuş ve anket yapılacak hanehalkı sayısının illere dağılımında, her ilin hane sayısının toplam hane sayısı içindeki payına bakılmıştır. Araştırmada kullanılan örneklem büyüklüğü formülü aşağıda verilmiştir (Collins, 1986).

$$
n=\frac{(t)^{2}\{1+(0,02)(b-1)\} P * Q}{(E)^{2}}
$$

t: \%95 önem seviyesindeki t tablo değeri

b: Örnekleme aşaması (bu araştırmada örnekleme aşaması tek olduğu için 1 alınmıştır)

$\mathrm{P}$ : incelenen olayın ana kitle içerisinde gerçekleşme olasılığı

Q: incelenen olayın gerçekleşmeme olasılığ

$\mathrm{E}$ : bu çalışmada kabul edilen hata payını $(0,05)$ ifade eder.

t: \%95 önem seviyesindeki t tablo değeri

Yukarıda örnek büyüklügünü belirlemede kullanılacak formülde örnekleme aşaması (b) 1 alındığında aşağıdaki formül elde edilir;

$$
n=\frac{(t)^{2}(P * Q)}{(E)^{2}}
$$

Araştırma kapsamına alınan hanelerin \%50 sinin organik süt için, senaryoda belirtilen şartlar sağlandığında belli bir fiyat pirimi vermeyi kabul eden hanelerin oranını göstermektedir. Böyle durumlarda, örnek büyüklügünün mümkün olduğu kadar büyük olmasını sağlamak için, $p(1-p)$ çarpımında en büyük değeri verecek olan $p=0,5$ değerinin kabul edilmesi tavsiye edilmektedir. Bundan dolayı, $\mathrm{p}=0,5$ olarak kabul edilmiştir. $\mathrm{Bu}$ araştırmada maksimum örnek büyüklüğüne ulaşmak için $p$ ve $q$ oranları \%50 alınmıştır. Yukarıda elde edilen formüle göre araştırmanın örnek büyüklüğü 1011 fakat analizler 1570 anket büyüklüğü üzerinden yapılmıştır.

Araştırma kapsamına alınan organik sütün içerisinde sağlığa zararlı hiçbir katkı maddesinin olmadığının anket yapılan deneğe garanti edilerek ürünün özellikli bir mal olduğu anlatılmıştır. Haliyle ürünün tüketiciye sağladığı değer serbest piyasa koşullarında gözlenemez. Organik ürünlerin piyasası sinırlı olduğundan organik sütün sağlık açısından güvenirliliğinin sağladığı faydanın piyasası bulunmamaktadır. $\mathrm{Bu}$ araştırmada değerinin belirlenmesine çalışılan ürün, özellikli ya da yarı özel nitelik taşıyan piyasası olmayan besin güvenirliği tüketiciye garanti edilmiş üründür. Ödeme istekliliği değerini ortaya koyabilmek için kullanılan KDY amacı, hem mal ve hizmetlerin kalitesinde ve miktarında meydana gelecek değişimlere karşı bireylerin ödeme isteklerini tahmin etmek, hem de ödeme isteği üzerinde etkisi bulunan değişkenleri tespit etmektir (Haab ve McConnell 2002). Ödeme istekliliği bilinmeyen bir değişken olarak, en yüksek ve en düşük ikinci fiyat tekliflerinin sorulması katılımcıların en yakın ödeme istekliliği miktarının bulunmasına yöneliktir. Çift sınırlı teklif fiyatlarına verilen cevaplar dört kategoriye ayrılmıştır; (1) $\left(-\infty, B_{L}\right)$ ankete katılan katılımciların her iki fiyat teklifini ret etme durumunu göstermektedir (hayır, hayır) ve bundan dolayı tüketicinin ödeme istekliliği miktarı düşük olan ikinci fiyat miktarının $\left(B_{L}\right)$ 'in altındadır. Bunun anlamı katılımcının ödeme istekliliği (Ö̇) miktarı $0<$ Ö̇ $<B_{L}{ }^{\prime}$ dir; (2) $\left[B_{L}, B_{I}\right.$ ) katılımcının kendisine sunulan ilk fiyat miktarını $\left(B_{I}\right)$ kabul etmemesi fakat daha düşük ikinci fiyat teklifini $\left(B_{L}\right)$ kabul etmesi durumunu yansitmaktadır (hayır, evet). İkinci sunulan teklif fiyatı ilk sunulan fiyat miktarından $\left(B_{L}\right)$ daha azdır. Bundan dolayı beklenilen Öİ miktarı en düşük ikinci fiyat teklif miktarı $\left(B_{L}\right)$ ve ilk fiyat teklif miktarları $\left(B_{I}\right)$ arasındadır ve katılımcının ÖI değeri $B_{I} \leq \ddot{\mathrm{O}} \dot{\mathrm{I}}<B_{L}$ arasındadır. (3) $\left[B_{I}, B_{U}\right)$ katılımc ilk teklif edilen fiyat $\left(B_{I}\right)$ miktarını kabul ettiğinde fakat ikinci teklif edilen fiyat $\left(B_{U}\right)$ miktarını ret ettiğinde (evet, hayır) oluşan durumdur. $\mathrm{Bu}$ durumda, katılımcılar için beklenilen ödeme istekliliği miktarı ilk teklif edilen fiyat miktarından daha yüksek fakat ikinci en yüksek teklif edilen fiyat $\left(B_{U}\right)$ miktarından daha düşük olmuştur. Bu sayede her 
bir katılımcının ödeme istekliliği $B_{\iota} \quad \leq \ddot{\mathrm{O} \dot{\mathrm{I}}<B_{U}}$ aralığındadır. (4) son kategori olan $\left[B_{U},+\infty\right)$, katılımcı artarda sorulan her iki fiyat teklifini de kabul etme (örneğin ilk ve ikinci fiyat teklifi) durumudur (evet, evet). Bu bağlamda katılımcıların niyetlendikleri Öİ miktarı teklif edilen ikinci en yüksek fiyat miktarından daha yüksektir ve $B_{U} \leq \ddot{\mathrm{O}} \dot{\mathrm{I}}<_{\infty}$ aralığındadır (Hanemann ve ark., 1991; Haab ve McConnell, 2002).

Tüketicilerin asıl ÖI miktarı göz önünde bulundurulursa, ÖI $\dot{I}_{i}$ olarak gösterilir ve çift sinırlı teklif fiyatlarının simetrik dağılımıyla normallik varsayımı altında Öİ'nin dört olasılığı aşağıda verilmiştir (Hanemann ve ark., 1991; Haab ve McConnell, 2002).

$$
\begin{aligned}
\operatorname{Pr}(y, n) & =\operatorname{Pr}\left(B_{L} \leq W T P<B_{U}\right)=\operatorname{Pr}\left(B_{L} \leq z^{\prime} \beta_{i}+u_{i}<B_{U}\right) \\
& =\operatorname{Pr}\left(\frac{B_{L}-z_{i}^{\prime} \beta_{i}}{\sigma} \leq \frac{u_{i}}{\sigma}<\frac{B_{U}-z_{i}^{\prime} \beta_{i}}{\sigma}\right) \\
& =\Phi\left(\rho B_{U}-z_{i}^{\prime} \theta_{i}\right)-\Phi\left(\rho B_{L}-z_{i}^{\prime} \theta_{i}\right)=\Phi\left(z_{i}^{\prime} \theta_{i}-\rho B_{L}\right)-\Phi\left(z_{i}^{\prime} \theta_{i}-\rho B_{U}\right) \\
\operatorname{Pr}(y, y)= & \operatorname{Pr}\left(W T P>B_{I}, W T P \geq B_{U}\right)=\operatorname{Pr}\left(z_{i}^{\prime} \beta_{i}+u_{i}>B_{I}, z_{i}^{\prime} \beta_{i}+u_{i} \geq B_{U}\right) \\
= & \operatorname{Pr}\left(u_{i} \geq B_{U}-z_{i}^{\prime} \beta_{i}\right) \\
= & 1-\Phi\left(\rho B_{U}-z_{i}^{\prime} \theta_{i}\right)=\Phi\left(z_{i}^{\prime} \theta_{i}-\rho B_{U}\right) \\
\operatorname{Pr}(n, y)= & \operatorname{Pr}\left(B_{L} \leq W T P<B_{I}\right)=\operatorname{Pr}\left(B_{L} \leq z_{i}^{\prime} \beta_{i}+u_{i}<B_{I}\right) \\
= & \operatorname{Pr}\left(\frac{B_{L}-z_{i}^{\prime} \beta_{i}}{\sigma} \leq \frac{u_{i}}{\sigma}<\frac{B_{I}-z_{i}^{\prime} \beta_{i}}{\sigma}\right) \\
= & \Phi\left(\frac{B_{I}-z_{i}^{\prime} \beta_{i}}{\sigma}\right)-\Phi\left(\frac{B_{L}-z_{i}^{\prime} \beta_{i}}{\sigma}\right)=\Phi\left(z_{i}^{\prime} \theta_{i}-\rho B_{L}\right)-\Phi\left(z_{i}^{\prime} \theta_{i}-\rho B_{I}\right) \\
\operatorname{Pr}(n, n)= & \operatorname{Pr}\left(W T P<B_{I}, W T P<B_{L}\right)=\operatorname{Pr}\left(z_{i}^{\prime} \beta_{i}+u_{i}<B_{I}, z_{i}^{\prime} \beta_{i}+u_{i}<B_{L}\right) \\
= & \operatorname{Pr}\left(z_{i}^{\prime} \beta_{i}+u_{i}<B_{L}\right)=\Phi\left(\frac{B_{L}-z_{i}^{\prime} \beta_{i}}{\sigma}\right)=1-\Phi\left(z_{i}^{\prime} \theta_{i}-\rho B_{L}\right)
\end{aligned}
$$

Burada (y,n), (y,y), (n,y) ve (n,n) sirasiyla "evet, hayır", "evet, evet", "hayır, evet" ve "hayır, hayır" olasılıklarını göstermektedir. $\rho=1 / \sigma, \theta_{i}=\beta_{i} / \sigma$ ve $\Phi$ kümülatif normal dağılımı (cdf) göstermektedir. z katılımcının sosyo-demografik ve ekonomik faktörlerinden oluşan bağımsız değişken setini, $u_{i}$ araştırmacı tarafından kontrol edilemeyen ve sistem dışı olan kalıntı değişkenini göstermektedir. Maksimum olabilirlik fonksiyonu (MOF) yukarıda verilen dört kategorideki olasılıklardan oluşmaktadır ve aşağıdaki gibi MOF'nun logaritmasını maksimize edecek sekilde parametre tahminleri oluşturulmuştur.

$$
\begin{aligned}
\ln L(\theta, \rho \mid z)= & \sum_{i=1}^{N_{L}}\left[d_{i}^{y n} \ln \left(\Phi\left(z_{i}^{\prime} \theta_{i}-\rho B_{L}\right)-\Phi\left(z_{i}^{\prime} \theta_{i} \rho B_{U}\right)\right)+d_{i}^{y y} \ln \left(\Phi\left(z_{i}^{\prime} \theta_{i}-\rho B_{U}\right)\right)\right]+ \\
& \sum_{i=N_{I}+1}^{N}\left[d_{i}^{n y} \ln \left(\Phi\left(z_{i}^{\prime} \theta_{i}-\rho B_{L}\right)-\Phi\left(z_{i}^{\prime} \theta_{i} \rho B_{I}\right)\right)+d_{i}^{n n} \ln \left(1-\Phi\left(z_{i}^{\prime} \theta_{i}-\rho B_{L}\right)\right)\right]
\end{aligned}
$$

MOF'nun parametrelerini tahmin ettikten sonra ödeme istekliliği miktarının medyanı şu şekilde hesaplanmıştır;

$$
\text { medyan } \ddot{O} \dot{I}=-\frac{1}{\hat{\rho}}\left(\bar{z}^{\prime} \hat{\theta}\right)
$$

Burada Öİ miktarı bağımsız değişkenlerin ortalama değerlerinin üzerinden hesaplanmıştır. Diğer taraftan bağımsız değişkenlerin medyan ödeme istekliliği üzerindeki birim (marjinal) etkiler aşağıdaki gibi hesaplanmıştır.

$$
\frac{\partial}{\partial z_{k}}(\text { medyan } \ddot{O} \dot{I})=-\frac{\hat{\theta}_{k}}{\hat{\rho}}
$$

Ayrıca çalışmamızda ortalama ödeme istekliliği, kırpılmış ortalama ödeme istekliliği ve düzeltilmiş kırpılmış ortalama ödeme istekliliği sırasıyla aşağıdaki gibi hesaplanmıştır (Rhee 2013; Haab ve McConell, 2002). 


$$
\begin{aligned}
& \text { Ortalama } \ddot{O} \dot{I}=\int_{0}^{\infty} \Phi\left(-\left(\bar{z}^{\prime} \hat{\theta}+\hat{\rho} \bar{B}\right)\right) d \bar{B} \\
& \text { Kırpılmışortalama } \ddot{O} \dot{I}=\int_{0}^{\max B} \Phi\left(-\left(\bar{z}^{\prime} \hat{\theta}+\hat{\rho} \bar{B}\right)\right) d \bar{B} \\
& \text { Düzeltilmişs kırpılmış ortalama } \ddot{O} \dot{I}=\int_{0}^{\max B} \frac{\text { Kırpılmış ortalama } \ddot{O} \dot{I}}{\Phi\left(-\left(\bar{z}^{\prime} \hat{\theta}+\hat{\rho}(\max B)\right)\right)} d(\max B)
\end{aligned}
$$

\section{BULGULAR ve TARTIŞMA}

Araştırma kapsamina alınan hanelerin

Araştırma kapsamına alınan hanelerin betimleyici istatistikleri Çizelge 3.1'de verilmiştir. Neoklasik talep teorisinde bir talep fonksiyonu sadece gelir ve fiyat gibi ekonomik faktörlere bağlı olsa da bireylerin tüketim davranışları sistematik olarak cinsiyet, yaş, eğitim gibi demografik faktörler tarafindan da etkilenebilmektedir (Aktaş, 2008).

Elde edilen verinin gerçeği yansıtması için 18 yaş üstü ve evde alışverişi yapan kişi anket görüşmesine alınmıştır. Katılımcıların yaklaşık \%75,1'i, 30 yaş veya altı ve 30-40 yaş arasındadır. Gıda ile ilgili yapılan çoğu araştırmada olduğu gibi hane alışverişlerinde ağırlıklı olarak kadın rol almaktadır (Dettmann ve Dimitri, 2010; Bernard ve Gifford, 2006). Çizelgede de görüldügü üzere ankete katılan erkek katılımcıların oranı $(\% 44,5)$ kadın katılımcılara göre daha düşük çıkmıştır. Araştırma kapsamına dâhil edilen yedi bölgede ortalama yaş 34 bulunmuştur Elde edilen bu sonuç Türkiye'nin yaş ortalaması (30) ile uyumlu olduğu görülmektedir. Görüşme yapılan hane reislerinin \%52,9'unun evli olduğu tespit edilmiştir. Tüketicilerin söz konusu ürünü satın almada bağlayıcı bir özellik olabileceği düşünülen hane reisinin sosyal güvencesinin olup olmaması durumu görüşme yapılan hanelerde yüksek çıkmıştır $(91,8)$. Ankete katılan hanelerin çok küçük bir kısmı $(\% 4,3)$ belediye ya da kaymakamlıktan ayni ya da nakdi yardım almıştır. Hanehalkı birey sayısı, yatay kesit verilerinin kullanıldığı talep çalışmalarında harcama üzerinde doğrudan etkili olan önemli sosyo-demografik faktörlerden bir tanesidir. Hanehalkı genişlik grupları incelendiğinde, hanehalklarının 1,7'sinin 0-5 arasında çocuğa sahip olduğu, \%21,9'unun 6-12 arasinda çocuğa sahip olduğu ve \%18'nin 13-17 arasında çocuğa sahip olduğu belirlenmiştir. Ortalama hanehalkı büyüklüğü ise 3,43 kişi olarak bulunmuştur. Adrese Dayalı Nüfus Kayıt Sistemi sonuçlarına göre; 2016 yılında Türkiye'de ortalama hanehalkı büyüklüğü 3,5 kişidir (TUIK 2016). Bundan dolayı elde edilen sonucun Türkiye ile örtüştüğünü söyleyebiliriz. Ankete katılan hanelerde, çalışan kişi sayısı ortalama 1,6 olarak bulunmuştur. Eğitim, satın alma davranışını ve satın alma eylemini direkt etkileyen bir değişkendir. Tüketicinin bilgi ve bilinç düzeyini etkileyen eğitim, tüketicinin ilgili ürünler konusunda tercihlerinin oluşumunu sağlayacaktır. Bu yüzden, hanehalkı reisinin eğitim durumu, tüketici bilincini ve sağlıklı ürünlere olan talebi yansitması dolayısıyla talep çalışmalarında önemli bir değişken olarak kullanılmaktadır. Görüşme yapılan hane reislerinin \% 1,8'i eğitimsiz, \%24'ü ilköğretim, \% 74 gibi önemli bir kısmı lise veya üniversite mezunu olduğu ortaya çıkmıştır. Toplam harcama, zenginlik, mülk gibi geçici özellikleri kullanılabilir gelirden daha iyi yansıttığından dolayı gelirin yerine toplam harcamanın kullanılması daha uygun olduğu düşünülmüştür. Bununla birlikte hanelerin beyan ettiği gelir bilgilerinde bazen tutarsızlıklar olabilmektedir. Dolayısıyla bu veri ile elde edilen parametre tahminleri yanlı olabilmektedir. Hanelerin aylık ortalama geliri için vekil alınan ortalama toplam harcama miktarı aylık yaklaşık 2 bin 700 TL olarak bulunmuştur ve söz konusu değişkenin standart sapması 2466.409 olup oldukça yüksek çıkmıştır. Kukla değişkenler için standart sapma çok önemli olmasa da gelir, harcama gibi sürekli değişkenler için oldukça önemlidir. Bundan dolayı çizelgeye göre, aylık hanehalkı harcamasının haneden haneye büyük değişkenlik gösterdiğini söyleyebiliriz.

Organik süt için Çift-Sınırlı Koşullu Değer Biçme yaklaşımı ile ilgili tanımlayıcı istatistikler

Kayıp ve aykırı gözlemler atıldıktan sonra 1470 hanede, 1 litre (lt) organik süt için kurgulanan senaryolar altında sunulan fiyat tekliflerinin tanımlayıcı istatistikleri verilmiştir. Sunulan fiyat tekliflerini senaryolar altında, kabul etme oranlarına bakıldığında deneklerin \%6,6'sı organik süt için her iki fiyat teklifine de "Evet" demişlerdir. İlk sunulan fiyat teklifine "Evet" ardından sunulan ikinci fiyat teklifine "Hayır" diyen katılımcıların oranı \%14,2'dir. İlk fiyat teklifine "Hayır" ikinci fiyat teklifine "Evet" diyenlerin oranı \%30,5'dur. Hem ilk fiyat teklifine hem de ikinci fiyat teklifine "Hayır" diyenlerin oranı \%48,7'dir. Elde sonuçlara göre teklif miktarı arttıkça ödeme istekliliği miktarının azaldığı gözlemlenmiştir. 
Çizelge 1.Türkiye'de hanelerin sosyo-demografik ve ekonomik faktörlerine ilişkin tanımlayıcı istatistikleri

\begin{tabular}{|c|c|c|c|}
\hline Değişkenler & Tanım & Ort. veya \%'ler & $\begin{array}{c}\text { Std. } \\
\text { Sapma }\end{array}$ \\
\hline \multicolumn{4}{|l|}{ Bağımsız değişkenler } \\
\hline Cinsiyet & Ankete katılan kişinin cinsiyeti Erkek ise 1, değilse 0 & 0,445 & 0,497 \\
\hline Medeni Durum & Ankete katılan kişi Evli ise 1, değilse 0 & 0,529 & 0,499 \\
\hline Yaş & Ankete katılan kişilerin ortalama yaşı & 34,178 & 10,888 \\
\hline Yaş1 & Ankete katılan kişinin yaşı $\leq 30$ ise 1 , değilse 0 & 0,442 & 0,496 \\
\hline Yaş2 & $30<$ katılımcının yaşı $\leq 40$ ise 1 , değilse 0 & 0,309 & 0,462 \\
\hline Yaş3 & Ankete katılan kişinin yaşı > 40 (referans grup) & - & - \\
\hline Güvence & Hane reisinin sosyal güvencesi varsa 1 , değilse 0 & 0,918 & 0,273 \\
\hline Yardim & Parasal ya da parasal olmayan yardım alınıyorsa 1 , değilse 0 & 0,043 & 0,204 \\
\hline Hane büyüklüğü & Anket yapılan hanelerde ortalama kişi sayısı & 3,431 & 1,487 \\
\hline Çalışan kişi sayısı & Anket yapılan hanelerde ortalama çalışan kişi sayısı & 1,563 & 0,769 \\
\hline Eğitimsiz & Katılımcı ilkokul bitirmemişse 1, ilkokul bitirmişse değilse 0 & 0,018 & 0,134 \\
\hline İlköğretim & Katılımcı ilkokul veya ortaokul bitirmişse 1 , değilse 0 & 0,240 & 0,427 \\
\hline Lise & Meslek ya da düz liseyi bitirmişse 1 , değilse 0 & 0,364 & 0,481 \\
\hline Üniversite & Yüksekokul, üniversite veya lisansüstü tamamlamışsa 1 , değilse 0 & 0,376 & 0,484 \\
\hline İşsiz & Katılımcının çalışma durumu işsizse 1 , değilse 0 & 0,074 & 0,262 \\
\hline Ev hanımı & Katılımcı ev hanımı ise 1 , değilse 0 & 0,197 & 0,398 \\
\hline Emekli & Katılımcı emekli ise 1 , değilse 0 & 0,039 & 0,194 \\
\hline Diğer Meslek & Katılımcı işçi, çiftçi, tüccar veya kamu çalışanı ise 1 , değilse 0 & 0,688 & 0,463 \\
\hline Gelir1 & Anket yapllan hanenin ayllk geliri < 2000 (referans grup) & - & - \\
\hline Gelir2 & $2000<$ Hane Geliri $\leq 4000$ ise 1, değilse 0 & 0,489 & 0,500 \\
\hline Gelir3 & Anket yapılan hanenin aylık geliri $>4000$ ise 1 , değilse 0 & 0,251 & 0,433 \\
\hline Maaş dışı Gelir & Hane reisinin maaş dışı bir gayrimenkulden geliri varsa 1 , değilse 0 & 0,147 & 0,354 \\
\hline Toplam harcama & $\begin{array}{l}\text { Anket yapılan hanede aylık ortalama mutfak, yakacak, ulaşım gibi } \\
\text { giderler (TL) }\end{array}$ & 2651,201 & 2466,409 \\
\hline Kronik Hastalık & Anket yapılan ailede bir kronik hastalık varsa 1 , değilse 0 & 0,196 & 0,397 \\
\hline Kirac1 & Anket yapılan hane kirada oturuyorsa 1 , değilse 0 & 0,463 & 0,498 \\
\hline Müstakil ev & Anket yapılan hane müstakil evde oturuyorsa 1 , değilse 0 & 0,180 & 0,385 \\
\hline Otomobil & Anket yapılan hanede otomobil varsa 1 , değilse 0 & 0,446 & 0,497 \\
\hline Hastaneye uzaklık & Hanenin yaşadığ yerin hastaneye uzaklığ $\leq 0.50 \mathrm{~km}$ ise 1 , değilse 0 & 0,436 & 0,496 \\
\hline Alış. mrkz.uzaklık & $\begin{array}{l}\text { Yaşanılan yerin alışveriş merkezine uzaklığı } \leq 0.50 \mathrm{~km} \text { ise1, değilse } \\
0\end{array}$ & 0,502 & 0,500 \\
\hline Akdeniz & Anketin yapıldığı il Adana ya da Antalya ise 1 , değilse 0 & 0,102 & 0,303 \\
\hline Ege & Anketin yapıldığı il İzmir ise 1 , değilse 0 & 0,095 & 0,294 \\
\hline Marmara & Anketin yapıldığı il İstanbul veya Bursa ise 1 , değilse 0 & 0,420 & 0,493 \\
\hline Karadeniz & Anketin yapıldığı il Samsun veya Trabzon ise 1 , değilse 0 & 0,048 & 0,214 \\
\hline İç Anadolu & Anketin yapıldığı il Ankara veya Kayseri ise 1 , değilse 0 & 0,210 & 0,408 \\
\hline Doğu Anadolu & Anketin yapıldığı il Erzurum veya Malatya ise 1 , değilse 0 & 0,038 & 0,191 \\
\hline Güneydoğu Anadolu & Anketin yapıldığı il Antep veya Diyarbakır ise 1 , değilse 0 & 0,082 & 0,275 \\
\hline Çocuk Sayısı 0-5 & Katılımcının sahip olduğu çocuk sayısı 0-5 ise 1 , değilse 0 & 0,187 & 0,477 \\
\hline Çocuk Sayısı 6-12 & Katılımcının sahip olduğu çocuk sayısı 6-12 ise 1 , değilse 0 & 0,219 & 0,524 \\
\hline Çocuk Sayısı 13-17 & Katılımcının sahip olduğu çocuk sayısı 13-17 ise 1 , değilse & 0,180 & 0,454 \\
\hline $\begin{array}{l}\text { Ebeveyn ve } 18 \text { yaş } \\
\text { üstü }\end{array}$ & Anne, Baba, 18 yaş üstü ortalama yetişkin sayısı & 2,799 & 1,219 \\
\hline \multicolumn{4}{|l|}{ Bağımlı Değişkenler } \\
\hline Organik Paket Süt & Hanede organik paket süt tüketiliyorsa 1 , değilse 0 & 0,136 & 0,342 \\
\hline
\end{tabular}

Organik süt için Çift Sınırlı Koşullu Değer Biçme yaklaşımından elde edilen maksimum olabilirlik tahmincileri ve birim (marjinal) etkileri

Organik süt için çift-sınırlı koşullu değer biçme yaklaşımından elde edilen maksimum olabilirlik tahmincileri ve birim (marjinal) etkileri üzerinde durulmuştur. Ekonomik teori ile uygunluk sağlayan istatistiki açıdan önemli parametrelerin tartışması yapılmıştır. Çizelge 2 de verildiği üzere ankete katılan cinsiyeti erkek olan denekler 1 lt'lik paketlenmiş organik süt için ve 20,6 kuruş daha az ödeme istekliliğinde bulunmuşlardır. Oysa Bernard ve Bernard (2009)'ın yapmış oldukları benzer araştırmada ankete katılan erkek ve yaşlı 
katılımcıların, içerisinde hiçbir antibiyotik ve kimyasal madde bulunmayan süt için ödeme istekliliği düzeylerinin yüksek olduğunu belirlemişlerdir. Analiz sonuçlarında elde edilen istatistiki açıdan önemli bir diğer değişken ise YAŞ2 (yaş aralığ1 30-40 arasında olan denekler) değişkenidir. Söz konusu denekler yaklaşık 29 kuruş fazla ödeme istekliliğinde bulunmuşlardır. Yaş arttıkça sağlıklı ürünlere olan talebin artabileceğini bu sonuca istinaden söyleyebiliriz. Mesleği ev hanımı olan denekler 1 lt'lik organik süt için 37 kuruş daha az ödeme istekliliği olasılığında bulunmuşlardır. Mesleği ev hanımı olan denekler belirli bir gelirleri olmadıklarından dolayı ve sütü sadece içimlik değil aynı zamanda diğer amaçlar için de kullandıklarından konvansiyonel süte göre daha pahalı olan organik süt için fazladan ödemeye razı olmadıklarını söyleyebiliriz. Gelir3 grubunda (aylık gelir $\geq 3000$ ) bulunan deneklerin 1 lt'lik organik süt için 53 kuruş daha fazla ödeme istekliliği olasılığında oldukları saptanmıştır. Hanelerin geliri arttıkça doğrusal olarak ödeme istekliliği eğilimleri de artmıştır. Konvansiyonel süte göre mevcut piyasa fiyatı daha pahalı olan organik süt ödeme istekliliğinde, gelirin önemli bir etken olduğunu söyleyebiliriz. Angulo ve Gil (2007)'in İspanya'da yapmış oldukları sertifikalı kırmızı et ödeme istekliliği olasılığı araştırmasında, ödeme istekliliği olasılığını etkileyen en önemli açıklayıcı faktör olarak hane gelirini bulmuşlardır ve ürünün sertifikalı olmasının tek başına tüketici tercihinde çok küçük bir rolünün olduğunu gelirin ise daha önemli bir faktör olduğunu belirtmişlerdir. Üretiminden tüketimine kadar tamamen organik yöntemlerle üretilen ve paketlenen organik süt için hanede kalp, tansiyon, şeker hastalığg gibi kronik hastalıkların bulunması değişkeni önemli çıkmıştır. $\mathrm{Bu}$ bağlamda, hanelerin tercihlerinin oluşumunda sağlık faktörünün önemli olduğu anlaşılmıştır. Modelde ele alınan 7 bölge değişkeninden sadece Marmara bölgesi değişkeni istatistiki açıdan önemli çıkmıştır. Bölgede yaşayan haneler modelde referans alınan Güneydoğu Anadolu bölgesine göre organik süt için mevcut piyasa fiyatı üzerinden 70 kuruş daha az ödeme yapmak istemişlerdir. Çizelge 3'te ödeme istekliliği miktarları için araştırmaya katılan her bir hanede medyan ödeme istekliliği yaklaşık 4,83 TL'dir. Ortalama 1 lt organik süt için her bir hane senaryo eşliğinde 4,82 TL ödeme yapmak istemişlerdir.

Çizelge 2. Organik süt için çift-sınırlı koşullu değer biçme yaklaşımından elde edilen maksimum olabilirlik tahmincileri ve birim (marjinal) etkileri

\begin{tabular}{|c|c|c|c|c|}
\hline \multirow{2}{*}{ Değişkenler } & \multicolumn{2}{|c|}{ Çift-sınırlı KDY yaklaşımı } & \multicolumn{2}{|c|}{ Marjinal Etkiler } \\
\hline & Katsayılar & t-değer & Katsayılar & t-değer \\
\hline Sabit sayı & $3,067 * * *$ & 11,618 & $4,695^{* * *}$ & 11,618 \\
\hline Cinsiyet & $-0,134^{*}$ & $-1,941$ & $-0,206^{*}$ & $-1,941$ \\
\hline Yaş1 & 0,124 & 1,491 & 0,190 & 1,491 \\
\hline Yaş2 & $0,185^{* *}$ & 2,197 & $0,283^{* *}$ & 2,197 \\
\hline Gelir2 & $0,202^{* *}$ & 2,575 & $0,309 * *$ & 2,575 \\
\hline Gelir3 & $0,347^{* *}$ & 3,466 & $0,531 * *$ & 3,466 \\
\hline Lise & $0,149 *$ & 1,757 & $0,229^{*}$ & 1,757 \\
\hline Üniversite & 0,074 & 0,826 & 0,113 & 0,826 \\
\hline İşsiz & $-0,063$ & $-0,511$ & $-0,096$ & $-0,511$ \\
\hline Ev hanımı & $-0,241^{* * *}$ & $-2,632$ & $-0,369^{* * *}$ & $-2,632$ \\
\hline İkamet1 & $0,305^{* *}$ & 2,097 & $0,467 * *$ & 2,097 \\
\hline Maaş dışı gelir & 0,095 & 1,087 & 0,146 & 1,087 \\
\hline Güvence & $-0,099$ & $-0,889$ & $-0,151$ & $-0,889$ \\
\hline Yardım & $-0,095$ & $-0,599$ & $-0,145$ & $-0,599$ \\
\hline Kronik Hast. & $0,193^{* *}$ & 2,451 & $0,295^{* *}$ & 2,451 \\
\hline Kiraci & $-0,099$ & $-1,485$ & $-0,151$ & $-1,485$ \\
\hline Müstakil ev & 0,140 & 1,613 & 0,214 & 1,613 \\
\hline Araba & 0,001 & 0,017 & 0,002 & 0,017 \\
\hline Hastaneye Uzaklık & $-0,093$ & $-0,361$ & $-0,034$ & $-0,361$ \\
\hline Alış.Mrkz.Uzaklık & $-0,033$ & $-0,537$ & $-0,051$ & $-0,537$ \\
\hline Akdeniz & $-0,130$ & $-0,908$ & $-0,200$ & $-0,908$ \\
\hline Ege & $-0,180$ & $-1,233$ & $-0,275$ & $-1,233$ \\
\hline Marmara & $-0,446^{* * *}$ & $-3,856$ & $-0,683^{* * *}$ & $-3,856$ \\
\hline Kdeniz & $-0,253$ & $-1,431$ & $-0,387$ & $-1,431$ \\
\hline İçAnadol & $-0,190$ & $-1,510$ & $-0,291$ & $-1,510$ \\
\hline D.Anadol & $-0,190$ & $-1,011$ & $-0,290$ & $-1,011$ \\
\hline Hane büyüklüğü & $-0,035$ & $-1,409$ & $-0,053$ & $-1,409$ \\
\hline Çalışan kişi sayısı & 0,010 & 0,204 & 0,015 & 0,204 \\
\hline Fiyat teklifi & $-0,653^{* * *}$ & $-31,754$ & & \\
\hline Olabilirlik değeri & $-1705,077$ & & & \\
\hline
\end{tabular}

Not: *** ve ${ }^{* * *}$ sirasıyla \%10, \%5 ve \%1 istatistiki önem düzeyini göstermektedir. 
Sonuçlarından elde edilen toplam ödeme istekliliği tahmin miktarları sirasıyla 96.520.000 TL, 96.520.000 TL, 95.400.000 TL, 103.400.000 TL'dir. Araştırma sonuçlarından elde edilen düzeltilmiş kırpılmış ortalama Öİ baz alındığında Türkiye'de yaklaşık 100 milyon TL'lik yüksek bir pazar potansiyelinin olduğu saptanmıştır. İlgili konuda yatırım yapmak isteyen yatırımcılar için bulunan 100 milyon TL'lik ekonomik değer referans alınabilecek bir değer olabilmektedir. Yatırımcılar litre başına organik süt için maliyeti 5,17 TL'nin altında bir üretim gerçekleştirebilirlerse kar sürdürülebilirliğini sağlayabileceklerini söyleyebiliriz. Organik süt için ortalama ödeme istekliliği önemli bulunmuştur (540.172).

Çizelge 3. Ödeme istekliliği (ÖI) değerleri ölçümü

\begin{tabular}{lcccc}
\hline & $\begin{array}{c}\text { Medyan Ö̇ } \\
\text { miktarı (fiyat) }\end{array}$ & $\begin{array}{c}\text { Ortalama Öİ } \\
\text { miktarı (fiyat) }\end{array}$ & $\begin{array}{c}\text { Krrpılmış ortalama } \\
\text { Öİ miktarı (fiyat) }\end{array}$ & $\begin{array}{c}\text { Düzeltilmiş kırpılmıs } \\
\text { ort. Öİ miktarı (fiyat) }\end{array}$ \\
\hline Öİ tahmini & $\begin{array}{c}4.83^{* * *} \\
(540.172)\end{array}$ & 4.83 & 4.77 & 5.17 \\
\hline $\begin{array}{l}\text { Toplam Ö̇̇ tahmin } \\
\text { miktarı (TL) }\end{array}$ & $96.520 .000 \mathrm{TL}$ & $96.520 .000 \mathrm{TL}$ & $95.400 .000 \mathrm{TL}$ & $103.400 .000 \mathrm{TL}$ \\
\hline
\end{tabular}

Not: *** ve ${ }^{* *}$ sirasiyla \%10, \%5 ve \%1 istatistiki önem düzeyini göstermektedir

Koşullu değerleme anketinin deneklere sorduğu sorularla, organik süt ürünün belirli bir özelliğinden yararlanabilmek için tüketicinin kabulleneceği parasal fedakârlıklar elde edilmiştir. Bu yöntemle birlikte önceden belirlenen koşullara göre oluşturulan senaryo ve bu senaryoya bağll olarak tüketicilerin davranışlarının nasıl değişim gösterdiği gözlemlenmiştir.

\section{SONUÇ ve ÖNERİLER}

Bugün dünyada hızlı nüfus artışına paralel olarak artan gıda ihtiyacı beraberinde açlık gibi önemli bir sorunu getirmektedir. Açlı̆̆ın giderilmesi tarımsal üretimin artırılmasına bağlıdır. Üretim artırılırken doğal kaynakların sürdürülebilirliğinin sağlanması alternatif üretim olarak karşımıza çıkan organik üretim ile sağlanabilecektir. Konu bu yönü ile ele alındığında dünyada artan bir hızda gelişen ve ülke ekonomilerine önemli katkı sağlayan organik üretim ülkemizde de her geçen yıl önem kazanmaktadır. Bu araştırmanın temel noktası, Türkiye'de organik yöntemlerle üretilmiş ve bu özelliği sertifikalandırılmış olan organik süte yönelik potansiyel talebin tahminlenmesidir. Eğer tüketiciler söz konusu ürüne yönelme eğilimi gösteriyorlar ve belirli bir fiyat pirimi vermeyi kabul ediyorlarsa, Türkiye'de organik süt için iç piyasanın potansiyelinden bahsedilebilecektir.

Araştırma bulgularına göre ödeme isteği, hane geliri ile doğru orantılı; cinsiyet ve meslek değişkeni ile ters orantılıdır. Haliyle, ürünün organik olma özelliği konusunda fazladan ödeme yapma olasılığı organik sütte, gelir ile doğru orantılı olarak arttığını söyleyebiliriz. Ödeme yapma olasılığı, içerisinde hiçbir kalıntıya rastlanılmayan sertifikalandırılmış organik sütün fiyatı yükseldikçe azalmaktadır. Söz konusu bulgularla ilgili değerlendirmeleri, üç madde altında toplamak mümkündür:
1. Sertifikalı organik süt için fiyat pirimi ödemeyi kabul eden tüketici grubundan oluşan hedef pazarın özellikleri,

2. Tüketicilerin ödeme isteklerinin doğrultusunda oluşturulabilecek politikalar,

3. Söz konusu ürünün elde edilen ödeme istekliliği değeri organik sütte yatırım yapmak isteyen yatırımcılar için veri kaynağı oluşturmaktadır.

Potansiyel talebin varlığı, Türkiye'de konvansiyonel üretim teknolojilerinin yerine çevre ile uyumlu içinde hiçbir kimyasal bulundurmayan organik girdilerin kullanımı ile yapılan organik üretimin gerekliliğine işaret etmektedir. $\mathrm{Bu}$ bağlamda, girdilerin yasal çerçevelerde kullanılmasına yönelik girdi ve fiyat politikalarının uygulanması ve bu konuda gerekli eğitimlerin verilmesiyle işlevsellik kazanacaktır.

\section{KAYNAKÇA}

Anonim 2014. Organik süt. http://www.anadolumor ganik.com/organik-süt2/coment-page-3/ (Erişim tarihi: 18.03.2014).

Angulo AM, Gil JM 2007. Risk perception and consumer willingness to pay for certified beef in Spain. Food Quality and Preference, 18(8):11061117.

Bernard JC, Bernard DJ 2009. What is it about organic milk? An experimental analysis. American Journal of Agricultural Economics, 91(3): 826-836.

Collins M 1986. Sampling editör: R. Worcester, vd. Consumer market researcher handbook. Elsevier Science Publishing Company inc., London.

Demiryürek K 2011. Organik tarım kavramı ve organik tarımın dünya ve Türkiye'deki durumu. GOÜ, Ziraat Fakültesi Dergisi, 28(1): 27-36.

Doğan N, Kızıloğlu S 2015. Konvansiyonel süt üreticilerinin organik süt üretimine bakış1: Gümüşhane ili örneği. Türk Tarım ve Doğa Bilimleri Dergisi, 2(3): 276-282. 
Greene WH 2003. Econometric Analysis. Pearson Education India, Delhi.

Gujarati DN 2009. Basic econometrics. Tata McGrawHill Education, New Delhi.

Haab TC, McConnell KE 2002. Social norms and illicit behavior: An evolutionary model of compliance. Journal of environmental management, 66(1): 6776.
Hanemann M, Loomis J, Kanninen B 1991. Statistical efficiency of double-bounded dichotomous choice contingent valuation. American Journal of Agricultural Economics, 73(4), 1255-1263.

Şengül M, Ürkek B 2013. Organik Süt. Sidas Medya Yayınları, 15s, İzmir. 